\title{
Retorika K.H. Junaedi Al-Baghdadi dalam Pengajian Dzikir Manaqib
}

\author{
Nida Farhatun Nisa ${ }^{1 *}$, Atjep Mukhlis ${ }^{1}$, Encep Taufik Rahman ${ }^{1}$ \\ 1Jurusan Komunikasi dan Penyiaran Islam, Fakultas Dakwah dan Komunikasi, UIN Sunan \\ Gunung Djati, Bandung \\ *Email: nidafarhatunnisa@gmail.com
}

\begin{abstract}
ABSTRAK
Penelitian ini bertujuan untuk mengetahui konsep retorika dan penerapan retorika K.H. Junaedi Al-Baghdadi, serta respon jemaah terhadap retorika K.H. Junaedi Al-Baghdadi. Adapun metode penelitian yang digunakan yaitu metode kualitatif dan pendekatan deskripstif. Metode kualitatif merupakan metode penelitian yang jenis data penelitian atau fenomena penelitian tidak diperoleh secara statistik. Pendekatan deskripsi berujuan untuk menjelaskan secara sistematis bidang tertentu secara factual dan cermat. Hasil yang didapat dalam penilitian ini yaitu K.H. Junaedi Al-Baghdadi memiliki konsep retorika sebagai seni berbicara yang menjadi ciri khas dari seorang praktisi dakwah dan gaya bicara tersebut tidak dibuat-buat melainkan keluar apa adanya. Retorika tersebut bertujuan untuk meyakini, menginspirasi dan mempengaruhi jemaah atas pesanpesan yang disampaikannya. Kemudian beliau juga menerapkan konsep ethos, pathos, dan logos serta lima imbauan persuasi dengan cara menggunakan katakata bijak atau motivasi, menggunakan bahasa yang bagusdan indah, serta menyentuh logika dan emosional.
\end{abstract}

Kata Kunci : Retorika; Tabligh; K.H. Junaedi Al-Baghdadi

\section{ABSTRACT}

This study aims to determine the concept and the application of K.H Junaedi Al-Baghdadi's rhetoric, as well as the response of the congregation to K.H Junaedi Al-Baghdadi's rhetoric.. The research method used is a qualitative method and descriptive approach. Qualitative methods are research methods whose research data types or research phenomena are not obtained statistically. The description approach aims to systematically explain certain fields factually and carefully. The results obtained in this research are K.H. Junaedi Al-Baghdadi has the concept of rhetoric as the art of speaking which is the hallmark of a da'wah practitioner and the style of speech is not artificial but comes out as it is. The rhetoric aims to believe, inspire and influence the congregation for the messages they convey. Then be also applied 
N. F. Nisa, A. Mukhlis, \& E. T. Rahman

the concepts of ethos, pathos, and logos and five persuasion calls by using wise words or motivation, using good and beautiful language, and touching logic and emotional.

Keywords : Rhetoric; Tabligh; K.H. Junaedi Al-Baghdadi

\section{PENDAHULUAN}

Retorika merupakan sebuah disiplin ilmu yang mempelajari seni berbicara yang diperlukan oleh setiap orang terutama bagi seorang komunikator. Retorika yang digunakan oleh seorang komunikator akan mempermudah ia untuk mempengaruhi khalayaknya sebagai mana Aristoteles mengansumsikan retorika sebagai seni untuk mempengaruhi orang lain (Rakhmat, 2012:2).

Sebagaimana dalam kegiatan dakwah, retorika sering kali digunakan untuk menjadikan pesan-pesan dakwah tersampaikan dan dipahami dengan baik oleh jemaah. Dakwah dapat diartikan sebagai aktivitas untuk memotivasi atau mendorong orang lain dengan pengetahuan yang mendalam agar menempuh jalan Allah SWT. Dalam artian ini, dakwah disampaikan dengan cara damai dan lebih mengutamakan aspek kognitif (intelektual) dan afektif (emosional) (Ismail, dkk, 2013:29-30).

Namun kegiatan dakwah yang dilakukan sering kali terdengar monoton, hal tersebut dikarenakan kegiatan dakwah yang disampaikan dengan gaya bicara atau metode yang monoton pula. Maka dari itu seorang pelaku dakwah (da'i) perlu mengaplikasikan retorika dalam kegiatan dakwahnya. Adanya karakteristik gaya dan bahasa yang menarik, kegiatan dakwah yang dilakukan pun tidak lah monoton. Tentunya gaya bicara atau bahasa disesuaikan dengan mad'u yang akan dihadapi. Disinilah seorang da'i dituntut untuk berlaku arif atau bijaksana dalam berdakwah.

Di Indonesia sendiri sudah banyak da'i yang memiliki ciri khas saat menyampaikan pesan dakwahnya, seperti Aa Gym, Yusuf Mansur, Mamah Dedeh. Namun bukan hanya da'i yang terkenal melalui media mainstream saja yang memiliki kekhasan dalam berdakwah. Di Kecamatan Rengasdengklok Kabupaten Karawang terdapat salah satu da’i tersohor akan jemaahnya yang banyak, dan gaya bicara beliau ketika menasehati jemaahnya yaitu K.H Junaedi Al-Baghdadi.

K.H. Junaedi Al-Baghdadi atau lebih akrab disapa abah ini merupakan pemilik Pondok Pesantren Al-Baghdadi di Kecamatan Rengasdengklok Kabupaten Karawang. Beliau merupakan sosok da'i terkenal khususnya dikalangan masyarakat Karawang melalui kegiatan pengajian dzikir manaqib yang diadakan secara rutin.Selain tersohor akan jemaahnya yang banyak, K.H. Junaedi Al-Baghdadi dikenal sebagai da'i yang selalu mengedepankan tauhid, selalu memotivasi jemaahnya untuk terus mencari ridho Allah SWT. Beliau juga mempunyai selera humor yang bagus.

Pengajian dzikir manaqib merupakan pengajian yang mengadakan kgiatan 
tabligh akbar rutin yang dilaksanakan pada hari sabtu (malam minggu) mulai dari pukul 21.00 WIB hingga pukul 02.00 WIB. Pengajian tersebut berlangsung di lapangan terbuka yang sangatlah luas dan berdekatan dengan Pondok Pesantren milik K.H. Junaedi Al-Baghdadi. Selain K.H. Junaedi Al-Baghdadi yang mengisi pengajian tersebut, ada juga beberapa da'i dari berbagai kota yang sengaja ingin mengisi ceramahnya di Pengajian tersebut.

Pengajian dzikir manaqib tidak pernah sepi oleh jemaah melainkan selalu ramai dihadiri oleh jemaah setianya. Jemaah yang berdatangan bukan hanya masyarakat dari daerah Rengasdengklok saja melainkan dari daerah lain yang sangat jauh dengan lokasi pengajian. Bahkan sampai masyarakat dari luar Karawang pun banyak yang berdatangan untuk mengikuti pengajian dzikir manaqib tersebut.

Hal yang menjadi keunikan K.H. Junaedi Al-Baghdadi yaitu selain beliau suka menyanyikan lagu-lagu Islami yang berkaitan dengan tema bahasan dengan tujuan agar jemaah tidak merasa ngantuk atau bosan. Kemudian beliau juga pintar dalam bermain kata, dalam hal ini beliau selalu mengeluarkan kata-kata bijak, kata-kata motivasi yang mudah dipahami oleh semua kalangan.

Penelitian mengenai retorika memang sudah banyak dilakukan, namun penelitian mengenai K.H Junaedi Al-Baghdadi masih belum terlalu banyak. Salah satu penelitian mengenai K.H Al-Baghdadi yang ditemukan oleh peneliti yaitu Metode Tabligh K.H Junaedi Di Pondok Pesantren Al-Baghdadi Karawang oleh Ayu Holilah, Mahasiswa UIN Sunan Gunung Djati Bandung, 2017. Sejauh ini peneliti belum menemukan penelitian mengenai Retorika K.H Junaedi AlBaghdadi, maka dari itu peneliti tertarik untuk meneliti hal tersebut.

Berikut beberapa penelitian terdahulu mengenai retorika dan K.H. Junaedi Al-Baghdadi :

\begin{tabular}{|c|c|c|c|c|c|}
\hline Judul & Peneliti & Jurusan & Fakultas & Universitas & Tahun \\
\hline $\begin{array}{l}\text { Retorika } \\
\text { Dakwah K.H } \\
\text { Ahmad Sukino } \\
\text { dalam Program } \\
\text { Pengajian } \\
\text { AhadPagi Di } \\
\text { Radio MTA } \\
\text { 107.9 Surakarta }\end{array}$ & $\begin{array}{l}\text { Fendi } \\
\text { Kurniawan }\end{array}$ & KPI & $\begin{array}{l}\text { Dakwah } \\
\text { dan } \\
\text { Komunika } \\
\text { si }\end{array}$ & $\begin{array}{l}\text { UIN Sunan } \\
\text { Kalijaga } \\
\text { Yogyakarta }\end{array}$ & 2013 \\
\hline
\end{tabular}


N. F. Nisa, A. Mukhlis, \& E. T. Rahman

\begin{tabular}{|c|c|c|c|c|c|}
\hline $\begin{array}{l}\text { Retorika } \\
\text { Dakwah K.H } \\
\text { Muchammad } \\
\text { Syarif Hidayat }\end{array}$ & $\begin{array}{l}\text { Leiza } \\
\text { Sixmansyah }\end{array}$ & KPI & $\begin{array}{l}\text { Dakwah } \\
\text { dan } \\
\text { Komunika } \\
\text { si }\end{array}$ & $\begin{array}{l}\text { UIN Syarif } \\
\text { hidayatullah } \\
\text { Jakarta }\end{array}$ & 2014 \\
\hline $\begin{array}{l}\text { Retorika } \\
\text { Dakwah Pipike } \\
\text { Dian Irawati }\end{array}$ & $\begin{array}{l}\text { Eva } \\
\text { Damayanti }\end{array}$ & KPI & $\begin{array}{l}\text { Dakwahda } \\
\mathrm{n} \\
\text { Komunika } \\
\text { si }\end{array}$ & $\begin{array}{l}\text { UIN Syarif } \\
\text { hidayatullah } \\
\text { Jakarta }\end{array}$ & 2014 \\
\hline $\begin{array}{l}\text { Retorika Tabligh } \\
\text { Ustadz Aam } \\
\text { AmirudinDalam } \\
\text { MeningkatkanPe } \\
\text { mahamanAkhlak } \\
\text { Jemaah } \\
\text { (StudiDeskriptifP } \\
\text { adaMajelisPercik } \\
\text { anIman di Masjid } \\
\text { Al-Murosalab) }\end{array}$ & $\begin{array}{l}\text { Hani } \\
\text { Hadiyanti }\end{array}$ & KPI & $\begin{array}{l}\text { Dakwah } \\
\text { dan } \\
\text { Komunika } \\
\text { si }\end{array}$ & $\begin{array}{l}\text { UIN Sunan } \\
\text { Gunung Djati } \\
\text { Bandung }\end{array}$ & 2014 \\
\hline $\begin{array}{l}\text { RetorikaDakw } \\
\text { ah K.H } \\
\text { Faturrohman }\end{array}$ & $\begin{array}{l}\text { Fatimatu } \\
\text { Zahro }\end{array}$ & KPI & Dakwah & $\begin{array}{l}\text { IAIN } \\
\text { Purwokerto }\end{array}$ & 2017 \\
\hline $\begin{array}{l}\text { MetodeTabligh } \\
\text { K.H Junaedi } \\
\text { Di } \\
\text { PondokPesantr } \\
\text { en Al- } \\
\text { Baghdadi } \\
\text { Karawang }\end{array}$ & Ayu Holilah & KPI & $\begin{array}{l}\text { Dakwah } \\
\text { dan } \\
\text { Komunika } \\
\text { si }\end{array}$ & $\begin{array}{l}\text { UIN Sunan } \\
\text { Gunung Djati } \\
\text { Bandung }\end{array}$ & 2017 \\
\hline
\end{tabular}

Berdasarkan uraian latar belakang masalah di atas, maka dapat dijadikan beberapa rumusan masalah yaitu; (1) Bagaimana konsep retorika K.H. Junaedi Al-Baghdadi dalam pengaiian dzikir manaqib?; (2) Bagaimana penerapan retorika K.H. Junaedi Al-Baghdadi dalam pengajian dzikir manaqib?; (3) Bagaimana respons jemaah terhadap retorika K.H. Junaedi Al-Baghdadi dalam pengajian dzikir manaqib?

Metodologi penelitian yang digunakan adalah metode kualitatif dengan pendekatan studi deskriptif. Metode kualitatif merupakan penelitian yang digunakan untuk menggambarkan dan menganalisa peristiwa, sikap atau aktivitas 
sosial baik secara individual maupun kelompok. Metode kualitatif juga merupakan jenis metode penelitian yang mana data penelitian atau fenomena penelitian tidak diperoleh secara statistik atau hitungan (Shodiq, dkk, 2013:4).

Pendekatan deskripsi berujuan untuk menjelaskan secara sistematis bidang tertentu secara faktual dan cermat. Dengan cara mengamati fenomena penelitian, mencatat dan mengategorikannya, pendekatan deskripsi tidak akan menjelaskan hubungan ataupun menguji hipotesis dan sebisa mungkin menjaga keaslian gejala atau fenomea yang diteliti (Sadiah, 2015:19).

Peneliti mengunakan metode kualitif dikarenakan penelitian ini lebih menekankan pada aspek makna dan tidak adaya hubungan dengan kuantitas ataupun generalisasi. Penelitian ini juga akan menggambar Retorika K.H Junaedi AL-Baghddadi sebagai fenomena penelitian, sehingga dengan metode kualitatif dan pendekatan studi deskriptif ini akan dirasa pas untuk mengupas rumusan masalah dalam penelitian ini.

\section{LANDASAN TEORITIS}

Untuk memecahkan rumusan masalah, penelitian ini menggunakan beberapa teori yaitu teori retorika dan tabligh. Secara etimologi, retorika berasal dari bahasa latin yaitu rhetorica yang artinya seni berbicara (The Art Of Speech) (Moede, 2001:38). Secara terminologi, banyak sekali definisi retorika yang dibuat oleh para pakar retorika. Menurut Syukir retorika secara istilah diartikan sebagai ilmu yang mempelajari mengenai berbicara dengan baik dihadapan orang banyak. (Syukir, 1983:104). Adapun menurut Hendrikus menyebutkan bahwa berbicara merupakan inti dari retorika. Berbicara adalah salahsatu kemampuan khusus manusia. Maka dari itu bahasa dan pembicaraan lahir saat manusia mengutarakan apa yang ada dipikirannya kepada lawan bicaranya (Hendrikus, 1991: 14).

Pada Abad pertengahan berlangsung (400-1400), di Eropa terjadi pertemuan antara orang Eropa dan Islam, mereka telah mengembangkan khazanah Yunani dan dengan terjadinya Perang Salib yang menyebabkan timbulnya Renaissance. Renaissance membawa perkembangan retorika abad pertengahan kepada retorika modern. Roger Bacon (1214-1219) merupakan salah satu tokoh yang menguhubungkan peristiwa Renaissance dengan retorika modern. Ia berpendapat mengenai retorika dan proses psikologis yaitu“.... Kewajiban retorika ialah menggunakan rasio dan imajinasi untuk menggerakan kemauan secara lebih baik". Pada abad kedua puluh, retorika mengambil manfaat dari beberapa disiplin ilmu tertutama ilmu-ilmu perilaku seperti sosiologi dan psikologi. Sehingga hal tersebut pengertian retorika mulai mengalami perkembangan dan mengarah pada speech, speech communication,oral communication atau public speaking (Rakhmat, 2012: 12-14) 
N. F. Nisa, A. Mukhlis, \& E. T. Rahman

Menurut pandangan Lathief, tujuan dari pengguanaan retorika sebagai berikut; 1) Untuk menginformasikan yaitu retorika memiliki tujuan untuk memberikan pengetahuan atau penjelasan mengenai sesuatu kepada komunikan; 2) Untuk meyakinkan yaitu seseorang pembicara harus mampu meyakinkan lawan bicaranya atau komunikan atas apa yang ia sampaikan; 3) Untuk menginspirasi yaitu seorang public speaker harus mampu menginspirasi komunikan melalui gaya bicaranya. Melalui gaya bicara dan bahasa yang dapat menginspirasi maka dapat melahirkan sebuah kepercayaan dan menjadikan seorang public speaker tersebut memiliki kredibilitas; 4) Untuk menghibur yaitu retorika juga memiliki tujuan untuk menghibur andience, maka dari itu orator memiliki selera humor atau gaya humor yang bagus; 5) Untuk menggerakan yaitu setelah dapat meyakinkan audience, retorika bertujuan untukmenggerakan mereka agar melaksanakan apa yang disampaikan orator (Rousydiy, 1989: 234).

Aritoteles dan para ahli retorika klasik lainnya menyebutkan terdapat lima tahap dalam penyusunan pidato yang disebut sebagai The Five Canons of Rhetoric (Lima Hukum Retorika) yaitu; pertama,inventio (Penemuan) yaitu Penemuan disini berarti komunikator melakukan riset terhadap karakteristik audience sehingga dapat menetukan metode persuasi yang cocok dengan mereka (Rakhmat, 2012:7); kedua,despositio(Penyusunan) yaitu dalam tahap ini komunikator menyusun pesan menjadi tiga bagian yaitu: pendahuluan, badan, kesimpulan (Effendy, 2013:55); ketiga, elucotio (Gaya) yaitu seorang komunikator menggunakan bahasa yang sesuai untuk menyampaikan pesannya. Aristoteles memberikan nasihat yaitu : pilihlah diksi yang tepat, jelas, dan langsung; sampaikan kalimat yang indah, mulia, dan hidup; serta sesuaikan bahasa dengan materi, audience, dan komunikator; keempat, memorio (Memoria) yaitu pada tahap ini pembicara harus mampu mengingat apa yang ingin disampaikannya dengan mengatur bahan materi atau pesan yang akan disampaikan; kelima, pronuntiatio (Penyampaian) yaitu komunikator menyampaikan pesan yang telah ia siapkan secara lisan kepada khalayak. Selain bermain dalam kata-kata dan olah vokal, pada tahap ini komunikator juga harus mampu memainkan mimik, gesture tubuh agar tidak monoton dan mendapat perhatian dari khalayak (Rakhmat, 2012: 8).

Aristoteles yang merupakan tokoh retorika pada zaman Yunani mengemukakan bahwa terdapat tiga prinsip retorika yang dapat digunakan untuk mempengaruhi manusia saat melakukan pidato yaitu ethos, pathos, dan logos. Ethos merupakansebuah sikap atau tindakan seorang komunikator yang meyakinkan bahwa ia memang ahli dibidang tersebut, sehingga hal itu menjadikan audience yakin dan dapat mempercayai komunikator tersebut. Sedangkan pathos merupakan hal yang melibatkan perasaan atau emosi (imbauan emosional). Pathos ini biasanya dapat tercermin dari gaya penyampaian atau bahasa yang digunakan komunikator yang mampu membangkit semangat atau perasaan komunikannya (Effendy, 1993: 352). Logos merupakan usahaseorang komunikator mendekati 
audience melalui otak atau pemikirannya. Komunikator dituntut untuk meyakinkan khalayak dengan perkataannya yang logis dengan mengajukan bukti (Rakhmat, 2012: 7).

Menurut Jalaludin Rakhmat, seorang komunikator perlu memiliki prinsip dalam menyampaikan pidato, salah satunya yaitu penggunaan bentuk persuasi yang meliputi; 1)imbauan rasional atau disebut juga dengan logos; 2) Imbauan emosional atau bisa disebutjuga dengan pathos; 3) Imbauan takut yaitu imbauan yang digunakan untuk membuat perasaan orang lain menjadi cemas, khawatir,bahkan mengancam serta dapat membangkitkan perasaan emosi; 4) Imbauan ganjaran yaitu Imbauan ganjaran adalah imbauan yang dapat memberikan kesenangan kepada audience atas perjanjian sesuatu yang dapat memberikan mereka imbalan atau pahala; 5) Imbauan motivasional yaitu imbauan yang digunakan untuk menyentuh kondisi internal audience (Rakhmat, 2003: 294-297).

Selain menggunakan teori retorika, peneltian juga menggunakan teori tabligh sebagai landasannya. Secara terminologi, tabligh merupakan salah satu bentuk dakwah dengan cara menyampaikan atau mentransmisikan ajaran Islam melalui mimbar atau media massa (cetak atau elektronik) dengan sasaran orang banyak (Sukayat, 2015:33). Menurut Aep Kusnawan, jika dilihat dari segi pelaksanaannya terdapat beberapa bentuk pada aktivitas tabligh yaitu khitobah (tabligh melalui mimbar), kitabah (tabligh melalui tulisan/media cetak), dan i'lam (tabligh melalui media elektronik) seperti tabligh memalui TV, radio, dan film (Kusnawan, 2004: 11).

Metode tabligh adalah suatu cara atau pendekatan tabligh yang dilakukan agar tercapainya tujuan dakwah yang telah ditentukan secara efektif dan efisien serta sesuai dengan kondisi dan situasi mad'u. Allah SWT mengemukakan mengenai metode-metode dalam berdakwah yaitu:

"Serulah (manusia) kepada jalan Tuhan-mu dengan hikmah dan pelajaran yang baik dan bantahlah mereka dengan cara yang baik. Sesungguhnya

Tuhanmu Dialah yang lebih mengetahui tentang siapa yang tersesat dari jalan-Nya dan Dialah yang lebih mengetahui orang-orang yang mendapat petunjuk" (Mushaf Aisyah, 2010: 281).

Berdasarkan ayat di atas terdapat tiga metode dakwah yaitu : Pertama, hikmah yang diartikan sebagai metode dakwah seorang da'i yang memiliki keterampilan dalam menyeleksi pesan sesuai dengan taraf kemampuan mad'u serta siatuasi dan kondisi mad'u. Kedua, Mau'izda Hasanah yang diartikan sebagai nasihat, bimbingan, peringatan yang baik. Apabila ingin menggunakan metode seperti ini, seorang da'i harus mampu memilah kata-kata atau diksi yang dapat menyentuh serta masuk kedalam hati mad'unya. Ketiga, Mujadala Bil Lati Hiya Ahsan yang diartikan sebagai metode dakwah seorang da'i mengajak kepada 
N. F. Nisa, A. Mukhlis, \& E. T. Rahman

mad'unya untuk bertukar pikiran, berdiskusi atau berdebat mengenai suatu persoalan tanpa adanya permusuhan ataupun pertengkaran (Munir, 2015: 8-17).

\section{HASIL DAN PEMBAHASAN}

Penelitian ini dilakukan kepada seorang mubaligh tersohor di Karawang yaitu K.H. Junaedi Al-Baghdadi. Beliau merupakan seorang mubaligh yang lahir pada 15 Agustus 1970 di desa Ajung, Kota Jember, Jawa Timur. Beliau merupakan anak tunggal yang terlahir dari keluarga seorang buruh tani. Beliau diberi nama oleh kedua orang tuanya Jumaadi Edy Sasmita, namun beliau kerap dipanggil Abah oleh para jemaah dan orang-orang terdekatnya. Keinginan menjadi mubaligh dalam diri beliau muncul karena beliau ingin mengamalkan ilmu-ilmu yang ia telah dapatkan dulu dari gurunya sehingga ilmu tersebut bermanfaat bagi orang lain. Disamping berdakwah, beliau berwirausaha atau bisnis untuk menunjang kehidupannya. Beliau tidak ingin menjadikan dakwah sebagai mata pencahariannya, maka dari itu beliau bekerja keras dalam usaha atau bisnisnya. Buah dari kerja keras dalam usahanya pun melahirkan Pondok Pesantren AlQodiri di Cibitung dan Pondok Pesantren Al-Baghdadi di Rengasdengklok, Karawang, Jawa Barat. Saat ini usaha beliau tidak hanya satu melainkan bermacam-macam, mulai dari usaha pulsa, air mineral Al-Baghdadi dan masih banyak lagi usahanya. Sebagian hasil dari usaha tersebut pun beliau pergunakan untuk biaya kehidupan para santri di pondok pesantrennya, karena pasalnya tidak ada biaya masuk atau SPP jika ingin mondok Pesantren Al-Baghdadi di Rengasdengklok, Karawang, Jawa Barat.Selain usaha dan dakwah sebagai kegiatan rutin seorang K.H. Junaedi AL-Baghdadi, jika dihari libur atau tidak ada kegiatan beliau melakukan kegiatan sebagaimana orang biasa lakukan seperti mengurus rumput, tanaman dan lain-lain, yang menunjukan beliau memiliki sifat rendah hati dan merakyat.

Kesibukan beliau saat ini yaitu mengurus pesantren Al-Baghdadi di Rengasdengklok Kabupaten Karawang dan mengisi pengajian dzikir manaqib Syekh Abdul Qadir Jaelani yang dihadiri oleh ratusan ribuan jemaah secara rutin setiap malam minggu di Rengasdengklok, Karawang, Jawa Barat. Sebagaimana yang telah dijelaskan bahwa pengajian manaqib ini selalu ramai oleh jemaahnya. tujuan beliau mengadakan pengajian dzikir manaqib disetiap minggunya yaitu agar kita, umat manusia, jemaah dzikir manaqib dapat selamat, selamat hakikat imannya, selamat dunia dan akhirat serta bisa bermanfaat bagi bangsa, agama, dan Negara (Hasil wawancara dengan K.H. Junaedi Al-Baghdadi pada tanggal tanggal 05 Mei 2018 di tempat Pengajian Dzikir Manaqib, RengasdengklokKarawang).

Berdasarkan penelitian yang dilakukan terdapat beberapa hasil penelitian yaitu mengenai konsep retorika K.H. Junaedi Al-Baghdadi, penerapan retorika K.H. Junaedi Al-Baghdadi dan respons jemaah terhadap retorika K.H. Junaedi 
Al-Baghdadi.

\section{Konsep Retorika K.H. Junaedi Al-Baghdadi}

Retorika merupakan hal penting bagi aktivis-aktivis atau praktisi-praktisi public speakeing, agar kegiatan tersebut mencapai target yang telah ditentukan. Salah satu kegiatan public speaking adalah dakwah. Dakwah merupakan suatu kegiatan yang bertujuan untuk mengajak manusiakepada jalan Allah agar mereka mendapatkan petunjuk dalam hidupnya dan dapat merasakan kebagahagiaan baik didunia maupun di akhirat (Tajiri, 2015: 16).

Begitu pun seorang K.H. Junaedi Al-Baghdadi yang merupakan seorang mubaligh sudah barang tentu perlu menyusun konsep retorika yang baik dan cocok bagi dakwahnya. Hal tersebut merupakan upaya beliau dalam menyampaikan pesan-pesan dakwahnya agar diterima serta dipahami oleh para jemaahnya. K.H. Junaedi pun mengaku bahwa beliau belum pernah belajar mengenai retorika dakwah. Akan tetapi beliau meyakini akan pentingnya memiliki konsep retorika bagi seorang mubaligh.Menurut seorang mubaligh yang kerap dipanggil abah oleh jemaahnya ini mengungkapkan bahwa retorika merupakan gaya bicara atau seni berbicara yang menjadi ciri khas dari seorang praktisi dakwah atau praktisi yang berkaitan dengan kegiatan berbicara di depan khalayak ramai. Retorika atau gaya bicara itu penting diperhatikan karena gaya ke-khasan dalam berbicara seorang mubaligh itu penting sebagai identitas mubaligh itu sendiri. Tidak hanya seorang mubaligh saja, seorang penyanyi pun sama, mereka memilikiciri khas dalam bernyanyi. Begitupun dengan mubaligh, satu sama lain itu memiliki ciri khas masing-masing. Sehingga retorika mubaligh yang menjadi ciri khas itu tidaklah dibuat-buat, dalam artian keluar dengan sendirinya yang merupakan karunia dari Allah (Hasil wawancara dengan K.H. Junaedi Al-Baghdadi pada tanggal tanggal 05 Mei 2018 di tempat Pengajian Dzikir Manaqib, Rengasdengklok-Karawang).

Ungkapan retorika menurut K.H. Junaedi Al-Baghdadi di atas, didukung dengan konsep retorika yang diungkapkan oleh Dori Wuwur Hendrikus bahwa berbicara merupakan inti dari retorika. Berbicara adalah salahsatu kemampuan khusus manusia. Maka dari itu bahasa dan pembicaraan lahir saat manusia mengutarakan apa yang ada dipikirannya kepada lawan bicaranya (Hendrikus, 1991: 14).

Beda halnya dengan konsep retorika yang dikemukakan oleh Jalaludin Rakhmat bahwa seseorang yang memiliki kemampuan berbicara dapat dikatakan sebagai bakat. Namun, kemampuan berbicara dengan baik, sistematis diperlukan pengetahuan dan pelatihan (Rakhmat, 2012:2). Sehingga dapat dikatakan definisi retorika yang diungkapkan oleh K.H. Junaedi Al-Baghdadi bertolak belakang dengan ungkapan Jalaludin Rakhmat yang menggap bahwa untuk memiliki 
N. F. Nisa, A. Mukhlis, \& E. T. Rahman

kemampuan seni berbicara atau retorika yang sistematis diperlukan pengetahuan dan pelatihan tidak hanya semata-mata bakat pemberian dari sang pencipta.

K.H. Junaedi Al-Baghdadi juga mengungkapkan mengenai konsep dalam penggunaan metode yang ia terapkan dalam dakwahnya yaitu metode cinta, karena menurutnya cinta itu mencakup semuanya. Melalui cinta kita dapat melahirkan kekuatan, dengan cinta kita dapat melahirkan energi yang luar biasa, dengan cinta kita dapat memberikan perubahan. Indonesia merdeka karena cinta, para pejuang mencintai negara Indonesia maka mereka berjuang dan bekerja keras agar Indonesia merdeka. Anak-anak sekolah karena orangtuanya cinta kepada cinta. Sehingga dunia ini menjadi sempurna kalo semua orang menjalani hidup ini penuh cinta (Hasil wawancara dengan K.H. Junaedi Al-Baghdadi pada tanggal tanggal 05 Mei 2018 di tempat Pengajian Dzikir Manaqib, Rengasdengklok-Karawang).

Beliau mempunyai konsep retorika dengan tujuan agar pesan dakwah dapat diterima serta dilaksanakan oleh jemaahnya sehingga pesan-pesannya mengandung nilai persuasi. Hal ini sesuai dengan tujuan retorika yang diungkapkan oleh Lathief yaitu to inform (Untuk Informasi), to entertain (Untuk Menghibur), to convince (Untuk meyakinkan), to inspire (Untuk menginspirasi), dan to actuate (Untuk menggerakan) (Lathief, 1989:234). Tujuan retorika dimaksudkan untuk menyampaikan ide, pikiran dan perasaan kepada orang lain agar mereka mengerti dan memahami apa yang disampaikan oleh retor (Zaini, 2017: 223). K.H. Junaedi Al-Baghdadi memainkan intonasi atau penekanan dalam pesan dakwahnya (Hasil wawancara dengan K.H. Junaedi Al-Baghdadi, pada tanggal 05 Mei 2018 di tempat Pengajian Dzikir Manaqib, Rengasdengklok-Karawang).

K.H. Junaedi Al-Baghdadi juga berpendapat mengenai dakwah yaitu sebagai bentuk kegiatan menyampaikan pesan yang bernilai amar ma'ruf nahi munkar, menyeru kepada kebaikan dan melarang kepada sesuatu yang buruk. Dakwah bagi saya adalah bagaimana cara mengajak umat atau manusia kepada yang baik. Ungkapan tersebut juga sesuai dengan tujuan beliau mengadakan pengajian dzikir manaqib disetiap minggunya yaitu agar kita, umat manusia, jemaah dzikir manaqib dapat selamat, selamat hakikat imannya, selamat dunia dan akhirat serta bisa bermanfaat bagi bangsa, agama, dan negara (Hasil wawancara dengan K.H. Junaedi Al-Baghdadi, pada tanggal 06 Januari 2018 di tempat Pengajian Dzikir Manaqib, Rengasdengklok-Karawang). Definisi dakwah dan tujuan dari pengajian dzikir manaqib yang diberikan oleh K.H. Junaedi AlBaghdadi tersebut sama halnya dengan ungkapan dakwah menurut Toha Jahja yaitu dakwah diartikan sebagai sebuah kegiatan mengajak orang lain dengan bijaksana kepada jalan Tuhan, mengerjakan perintah-Nya agar mereka meraih keselamatan dan kebahagiaan di dunia dan di akhirat (Toha, 1971:1).

Sebagaimana pada pembahasan sebelumnya bahwa terdapat bentukbentuk dakwah yaitu tabligh, irsyad, tadbir, dan tamkin atau tathwir, adapun 
bentuk dakwah yang dilakukan oleh K.H. Junaedi Al-Baghdadi yaitu tabligh. Tabligh merupakan salah satu bentuk kegiatan dakwah yang menggunakan lisan, tulisan, atau media elektronik untuk menyampaikan pesan-pesan dakwahnya kepada orang banyak (Sukayat, 2015:33). Kemudian dari berbagai pilihan media dalam berdakwah, media yang digunakan oleh K.H. Junaedi Al-Baghdadi adalah lisan. Beliau menyampaikan dakwahnya dengan oral yaitu ceramah di atas panggung dengan bantuan sarana lainnya seperti microphone dan sound system, serta infocusuntuk menunjang kelancaran proses dakwah beliau. Materi-materi dakwah yang beliau sampaikan punbegitu variatif, mulai dari ketauhidan, keyakinan atau keimanan, akhlak, syari'ah dan masih banyak lagi. Namun yang paling sering beliau sampaikan adalah tentang kecintaan dan keikhlasan. Berkaitan dengan metode dakwah yang diungkapkan oleh K.H. Junaedi AlBaghdadi, materi yang menjadi andalan beliau pun adalah materi tentang kecintaan, baik kecintaan kepada Allah, para rasul, para ulama, para wali, serta kecintaan antar sesama umat manusia (Hasil wawancara dengan K.H. Junaedi AlBaghdadi, pada tanggal 05 Mei 2018 di tempat Pengajian Dzikir Manaqib, Rengasdengklok-Karawang).

\section{Penerapan Retorika K.H. Junaedi Al-Baghdadi}

Retorika memiliki peran penting dalam kegiatan dakwah, sebagaimana yang telah dijelaskan bahwa tabligh merupakan bentuk dakwah yang dilaksanakan oleh K.H. Junaedi Al-Baghdadi, maka dari itu dalam pelaksanaan tabligh ini K.H. Junaedi Al-Baghdadi perlu menggunakan retorika yang baik agar pesan dakwah yang disampaikannya dapat diterima dan diaplikasikan oleh jemaahnya. Meskipun K.H. Junaedi Al-Baghdadi mengaku bahwa beliau belum pernah belajar mengenai retorika dakwah, berdasarkan yang terjadi dilapang beliau menerapkan beberapa hal yang menjadi prinsip-prinsip retorika.

Seperti yang dirumuskan oleh Aritoteles dan para ahli retorika klasik lainnya mengenai tahap-tahapdalam penyusunan pidato yang disebut dengan The Five Canons of Rhetoric (Lima Hukum Retorika), K.H. Junaedi Al-Baghdadi melaksanakan beberapa hal sebelum beliau berdakwah yaitu sebagai berikut:

Pertama, invention (penemuan) yaitu komunikator melakukan riset terhadap karakteristik audience juga menentukan tujuan dan mengumpulkan materi yang sesuai dengan audience (Rakhmat, 2012:8). Pengajian K.H. Junaedi Al-Baghdadi ini selalu ramai dengan jemaah yang datang dari berbagai macam kota atau daerah, sudah barang tentu memiliki karakteristik yang berbeda-beda mulai dari bahasa yang digunakan, watak, budaya kota atau daerah dan masih banyak lagi perbedaan lainnya. Langkah yang mudah untuk melakukan riset ini paling tidak K.H. Junaedi Al-Baghdadi mengabsen daerah atau kota kepada jemaahnya saat dipanggung, kota atau daerah mana saja yang hadir dalam 
N. F. Nisa, A. Mukhlis, \& E. T. Rahman

pengajian dzikir manaqib tersebut. Setidaknya dengan mengetahui daerah atau kota, K.H. Junaedi Al-Baghdadi sedikit mengetahui budaya-budaya yang melekat dijemaahnya.

Kedua, dispocitio (penyusunan) adalah tahap yang dilakukan komunikator dalam mengorganisasikan pesan. Aristoteles membagi susunan pesan menjadi tiga bagian yaitu: pendahuluan, badan, kesimpulan (Effendy, 2013:55). Namun K.H. Junaedi Al-Baghdadi, beliau mengaku tidak pernah melakukan persiapan apapun sebelum berdakwah, terutama mengonsep atau menysusun materi dakwah. Beliau mengaku spontanitas saja dalam menyampaikan materi selama tema pembahasannya sesuai dengan jemaah, karena mengingat beliau menggunakan metode cinta sebagai metode dakwah beliau. Menurut beliau karena dengan cinta semuanya akan mengalir begitu saja (Hasil wawancara dengan K.H. Junaedi Al-Baghdadi, pada tanggal 05 Mei 2018 di Rengasdengklok, Karawang).

Jika ditinjau dari jenis metode pidato, ceramah K.H. Junaedi Al-Baghdadi merupakan kegiatan penyampaiannya ceramah termasuk ke dalam jenis pidato dengan metode impromtu. Ceramah dengan metode impromtu merupakan ceramah atau pidato yang dilakukan dengan spontanitas, tidak ada persiapan apapun sebelum ceramah. Maka tak heran jika ada seorang pembicara yang menggunakan metode ini dalam kegiatan public speakingnya pesan yang disampaikan kurang sistematis, kemungkinan terdapat hal-hal yang lupa untuk disampaikan (Dinus.ac.id., Pidato: Bentuk, Tujuan, dan Metode, Diunduh pada tanggal 07 Mei 2018).

Ketiga, elocution (Gaya) adalah Aristoteles menganjurkan seorang komunikator agar memilih diksi yang tepat, jelas, dan langsung; sampaikan kalimat yang indah dan mulia (Rakhmat, 2012:8). Tahap ini selalu dilakukan oleh K.H. Junaedi Al-Baghdadi, pesan yang disampaikan selalu menggunakan diksi yang tepat, gaya penyampainnya juga bagus, serta beliau sering menggunakan kalimat-kalimat yang indah terutama jika beliau mengeluarkan kata-kata mutiara atau kata-kata motivasi yang bertujuan untuk menyentuh hati jemaah melalui bahasa serta gaya penyampaiannya.

Berikut terdapat beberapa kutipan ceramah K.H. Junaedi Al-Baghdadi yang menggunakan bahasa yang indah, intonasi yang lembut yaitu :

"Cintailah apa yang ingin kamu cintai didunia ini, tapi cepat atau lambat, diizinkan atau tidak, disengaja atau tidak, kamu pasti akan meninggalkan yang kamu cintai atau kamu yang akan ditinggali. Oleh karena itu, berbuatlah apa yang kamu mau, semua pasti ada balasannya. Cintailah apa yang ingin kamu cintai, tapi suatu saat kamu pasti akan meninggalkannya." (Ceramah K.H. Junaedi Al-Baghdadi, pada tanggal 03 Mei 2018 di Rengasdengklok, Karawang) 
"Cukup kau cari cintanya Allah, maka semua itu akan diberikan kepadamu, karena orang yang mencintai pasti selalu ingin memberi, dan yang diberikan selalu yang disukai dan disenangi. Betul ?. Jadi jangan kau cari surga, jangan kau cari pahala dalam ibadahmu, tapi yuk kita bersamasama cari cintanya Allah.” (Ceramah K.H. Junaedi Al-Baghdadi, pada tanggal 03 Mei 2018 di Rengasdengklok, Karawang).

Keempat, memoria (memorio) adalah pada tahap ini pembicara harus mampu mengingat apa yang ingin disampaikannya dengan mengatur bahan materi atau pesan yang akan disampaikan (Rakhmat, 2012:8). K.H. Junaedi AlBaghdadi yang jarang melaksanakan tahapan ini karena materi yang akan disampaikan tidak dikonsep terlebih dahulu, sehingga beliau cukup mengingat tema bahasan, ayat-ayat pendukung, selebihnya beliau akan berbicara sesuai dengan wawasan dan kehendak hati beliau.

Kelima, pronountiatio (penyampaian) adalah Selain bermain dalam kata-kata dan olah vokal, pada tahap ini komunikator juga harus mampu memainkan mimik, gesture tubuh agar tidak monoton dan mendapat perhatian dari khalayak. K.H. Junaedi kerap memainkan mimik wajah sesuai dengan pesan yang dilontarkan, mimik tersebut digunakan untuk memperkuat makna dari pesan yang dilontarkan. Kemudian berbicara tentang gesture tubuh, beliau hanya memainkan gerakan tangan sebagai gesture tubuh untuk mencuri perhatian jemaahnya.

Selain menerapkan lima dasar hukum retorika, K.H. Junaedi Al-Baghdadi juga menerapkan prinsip persuasi dalam pidato oleh Aristoteles yaitu ethos, pathos, dan logos. Pertama, ethos yaitu sebuah sikap atau tindakan seorang komunikator yang meyakinkan bahwa ia memang ahli dibidang tersebut (Effendy, 1993:352). K.H. Junaedi Al-Baghdadi yang bertindak sebagai komunikator atau mubaligh harus meyakinkan jemaahnya bahwa apa yang disampaikannya benar, wawasan yang dimilikinya pun luas sehingga para jemaah tidak ragu untuk mempercayai kebenaran apa yang beliau sampaikan. Berikut salah satu kutipan ceramahnya untuk meyakinkan jemaahnya :

"Kata Allah, "Jangan takut, jangan Khawatir, dan bergembiralah menjadi orang yang Istiqomah" kalo hari ini kamu banyak hutang, madeg, mantep, netep nyecep lah kepada Allah. Hari ini saya dikejar hutang, saya yakin yang bisa membuka jalan, yang bisa lunasin, bukan usaha saya, bukan siapa-siapa, tapi yang akan membuka jalan lunas adalah Allah. Kalo sudah ada keyakinan seperti itu, kamu ndak usah khawatir, bergembiralah walaupun ditagih-tagih. Inikan kata Allah loh, bukan abah yang ngomong ya." (Ceramah K.H. Junaedi Al-Baghdadi, pada tanggal 05 Mei 2018 di Rengasdengklok, Karawang).

Kedua, pathos adalah prinsip yang harus diterapkan oleh seorang 
N. F. Nisa, A. Mukhlis, \& E. T. Rahman

komunikator agar mampu menyentuh perasaan, emosi, harapan, kebencian, serta kasih sayang komunikannya (Rakhmat, 2012:7). Prinsip ini menjadi prinsip yang paling kuat diterapkan oleh K.H. Junaedi Al-Baghdadi dalam dakwahnya, beliau selalu menekankan pesan-pesan kecintaan sehingga beliau selalu mengeluarkan kata-kata bijak, kata-kata motivasi dengan gaya penyampaianya yang halus, lembut. Hal tersebut dapat membuat haru dan jemaahnya merasa tersentuh akan kata-kata yang dikeluarkan,sebagaimana kutipan ceramahnya berikut ini :

"Karena tanpa cinta, sulit kita berma'rifat kepada Allah. Karena cinta itu seperti yang abah bilang cinta dapat menembus ruang dan waktu, dengan cinta hidup ini menjadi indah, cinta sejati abadi dalam segala kehidupan. Jadi kalo kehidupan kita didasari dengan cinta sejati, maka disitu tidak ada yang namanya kepudaran cinta. Makanya saya katakan, dengan cinta hidup ini menjadi indah, apa yang tidak indah dengan cinta, saudaraku? Apa yang tidak indah? Hidup digubuk sengsara, kalo dihuni oleh dua insan yang bercinta itu bak sama dengan tinggal di istana... Sekalipun dia hanya beralaskan tikar, dengan tempat tidur yang terbuta dari belahan bambu, tapi kita tidur dengan orang yang sangat kita cintai apalah artinya tidur diatas springbed tanpa kekasih yang mendampingi." (Ceramah K.H. Junaedi Al-Baghdadi, pada tanggal 17 Oktober 2017 di Rengasdengklok, Karawang).

Ketiga, logos adalah prinsip yang harus diterpakan oleh komunikator untuk meyakinkan khalayak dengan perkataannya yang logis dengan mengajukan bukti (Rakhmat, 2012:7). Beliau kerap menggunakan contoh atau analogi agar mudah dipahami. Kemudian selain itu, beliau juga selalu menggunakan kata-kata yang logis dan mudah dipahami oleh akal atau pikiran siapapun yang mendengarkannya. Berikut ini beberapa ungkapan-ungkapan logis dalam cermahnya :

"Cukup kau cari cintanya Allah, maka semua itu akan diberikan kepadamu, karena orang yang mencintai pasti selalu ingin memberi, dan yang diberikan selalu yang disukai dan disenangi. Betul ?. Jadi jangan kau cari surga, jangan kau cari pahala dalam ibadahmu, tapi yuk kita bersamasama cari cintanya Allah." (Ceramah K.H. Junaedi Al-Baghdadi, pada tanggal 03 Desember 2017 di Rengasdengklok, Karawang).

"Jangan pernah orang itu ngomong "aku mencintai Allah" sebelum dia membuktikan kecintaanya kepada sesamanya" Omong kosong dia bilang cinta kepada Allah, kalo orang terdekatnya pun ia tidak cintai. Betul ? Maka kalo ada jemaah yang beli ketoprak kemudian teman yang disebelahnya tidak ditawari, maka cinta jemaah kepada Allah masih kecil. Punya kepekaan, punya kepedulian yang tinggi. Nah ketika kau punya kepekaan yang tinggi itu, maka Allah pun akan peka atas kamu. Ketika kamu punya kepedulian yang tinggi seperti itu, Allah pun akan peduli 
atas kamu." (Ceramah K.H. Junaedi Al-Baghdadi, pada tanggal 17 Oktober 2017 di Rengasdengklok, Karawang).

Sama halnya dengan prinsip retorika perusiasi yang diungkapkan oleh Jalaludin Rakhmat yaitu beliau juga menerapkan kelima imbauan yaitu imbauan rasional, emosional, takut, ganjaran, dan motivasional. Akan tetapi K.H. Junaedi Al-Baghdadi sangat kurang dalam memberikan imbauan takut, pasalnya beliau dalam setiap ceramahnya selalu berbicara tentang kecintaan, keikhlasan, keindahan berma'rifat, sehingga sangat jarang ditemukan imbauan takut (Rakhmat, 2003: 294-297).

\section{Respons Jemaah terhadap Retorika K.H. Junaedi Al-Baghdadi}

Sebagaimana dalam ilmu komunikasi disebutkan mengenai macam-macam respons atau pengaruh yang dihasilkan yaitu pertama, kognitif merupakan respons ini berkaitan dengan pengetahuan atau informasiyang didapat, sehingga kita dapat belajar menganalisis terhadap sesuatu hal. Kedua, afektif merupakan respons ini berkaitan dengan emosional, sikap, keyakinan yang ditimbulkan setelah mengalami suatu hal. Ketiga, psikomotorik merupakan respons ini berkaitan dengan perilaku baru yang dihasilkan setelah mengalami suatu hal.

Berikut ini terdapat beberapa respons atau tanggapan mengenai retorika K.H. Junaedi Al-Baghdadi saat beliau melakukan tabligh yaitu sebagai berikut :

Pertama, beliau itu orang jember sehingga bahasa yang digunakan ketika beliau ceramah itu memakai bahasa Indonesia agarjemaahnya bisa mengerti. Selain itu gaya bicara atau retorika beliau saat ceramah itu simple, susunannya mapan, sistematis sehingga tidak melantur kemana-mana. Ceramahnya juga enka didengar, maka dariu itu jemaahnya semakin kesini semakin bertambah. Mulai dari Banten, Sumatra, Bogor, Sukabumi, Jakarta dan masih banyak lagi (Wawancara dengan Pak Odih selaku jemaah K.H. Junaedi Al-Baghdadi, pada tanggal 05 Mei 2018 di Rengasdengklok-Karawang).

Kedua, gaya bicara yang digunakan oleh abah itu simple, mudah dimengerti, dan beliau itu kalo ceramah tidak menunjukan sosok beliau yang merupakan seorang kiayi sehingga jemaah pun rilex mendengarkan ceramahnya, seperti sedang diberi nasihat oleh orang tua sendiri (Wawancara dengan Pak Fathul Rofi selaku jemaah K.H. Junaedi Al-Baghdadi, pada tanggal 05 Mei Januari 2018 di Rengasdengklok-Karawang).

Ketiga, gaya bicara abah itu bagus, bahasa yang digunakan itu mudah dipahami dan tidak menyinggung perasaan orang juga. Apalagi jika abah sedang berbicara mengenai kecintaan kepada Allah, saya merasa tersentuh dengan gaya penyampaiannya yang lembut dan sampai ke hati saya. Maka dari itujika abah sudah mulai naik ke panggung, perhatian saya langsung tertuju ke beliau, menikmati dan memahami apa yang beliau sampaikan (Wawancara dengan $\mathrm{Bu}$ 
N. F. Nisa, A. Mukhlis, \& E. T. Rahman

Suryani selaku jemaah K.H. Junaedi Al-Baghdadi, pada tanggal 05 Mei 2018 di Rengasdengklok-Karawang).

Keempat, menurut saya gaya bicara abah dalam menyampaikan ceramahnya tidak membosankan, selalu ada humor yang dilontarkan, terkadang juga ada nyanyian dari Abah yang bikin kita jemaahnya menjadi tidak mengantuk (Wawancara dengan Pak Trisno selaku jemaah K.H. Junaedi Al-Baghdadi, pada tanggal 06 Januari 2018 di Rengasdengklok-Karawang).

Kelima, menurut saya gaya bicara abah saat berdakwah itu tidak seperti ustadz-ustadz yag lainnya, dalam artian beliau memposisikan diri denganjemaahnya itu bukan seorang kiayi dengan jemaah tapi seperti keluarga, sebagaimana dakwahnyayang selalu berisi nasihat atau petuah.Dalam ceramahnya beliau juga menggunakan bahasa yang mudah dimengeri, mudah dicerna, sehingga mudah dipelajari oleh jemaahnya (Wawancara dengan Pak Sahnawi selaku jemaah K.H. Junaedi Al-Baghdadi, pada tanggal 05 Mei 2018 di Rengasdengklok-Karawang).

Keenam, berdasarkan pengamatan saya sebagai jemaah beliau, gaya bicara abah saat berdakwah itu beraneka ragam, dalam artian abah terkadang menggunakan intonasi yang rendah atau lemah lembut, tapi terkadang juga menggunakan intonasi tinggi atau tegas, sehingga pesan yang disampaikan juga mudah mengerti (Wawancara dengan Pak Muslim selaku jemaah K.H. Junaedi Al-Baghdadi, pada tanggal 05 Mei 2018 di Rengasdengklok-Karawang).

Ketujuh, penyampaian abah itu berbeda dengan gaya penyampain ustadzustadz lainnya, jika abah sedang ceramah, tapi tidak terdenegar seperti ceramah dan terkesan sedang mengobrol atau berdiskusi dengan jemaahnya. Apa yang disampaikan beliau pun selalu nerap dipikiran saya Wawancara dengan Bu Titi selaku jemaah K.H. Junaedi Al-Baghdadi, pada tanggal 06 Januari 2018 di Rengasdengklok-Karawang).

Kedelapan, bagi saya, gaya bicara Abah itu seimbang, dalam artian Abah memakai nada keras dan tinggi jika materi yang dibahas adalah hal-hal yang bersifat dosa atau dilarang oleh Allah, sehingga terdapat ketegasan argumen. Akan tetapi beliau juga kerap menyampaikan dengan gaya bicara lemah lembut jika sedang membahas tentang akhlak baik, amal shaleh dan jika sedang menasihati jemaahnya (Wawancara dengan Bu Yuyum selaku jemaah K.H. Junaedi Al-Baghdadi, pada tanggal 06 Januari 2018 di RengasdengklokKarawang).

Kesembilan, tanggapan saya mengenai gaya bicara atau gaya penyampaian abah itu sangat kalem, tenang, tapi terkadang abah juga tegas juga sehingga membuat saya enak jikamendenger ceramahnya (Wawancara dengan Pak Rumat selaku jemaah K.H. Junaedi Al-Baghdadi, pada tanggal 05 Januari 2018 di Rengasdengklok-Karawang).

Kesepuluh, gaya bicara abah menurut saya itu bagus, bahasa yang 
digunakan abah saat berceramah sangat mudah dimengerti, dan mendetail sehingga pesan yang disampaikan pun terdengar jelas (Wawancara dengan Pak H.Sujono selaku jemaah K.H. Junaedi Al-Baghdadi, pada tanggal 05 Januari 2018 di Rengasdengklok-Karawang).

\section{PENUTUP}

Berdasarkan hasil penelitian dan pembahasan dapat ditarik kesimpulan yaitu pertama, konsep retorika K.H. Junaedi sama halnya dengan konsep retorika menurut Dori Wuwur Hendrikus yaitu retorika sebagai seni berbicara yang menjadi ciri khas dari seorang praktisi dakwah dan gaya bicara tersebut tidak dibuat-buat melainkan keluar apa adanya. kemudian tujuan pengunaan retorika K.H. Junaedi Al-Baghdadi sama halnya dengan tujuan retorika menurut Lathief yaitu agar pesan dakwah dapat diterima serta dilaksanakan oleh jemaahnya sehingga pesan-pesannya mengandung nilai persuasi.

Kedua, penerapan retorika K.H. Junaedi Al-Baghdadi yaitu retorika yang bersifat persuasi, agar jemaah tidak hanya memahami apa yang beliau sampaikan akan tetapi melaksanakan apa yang beliau sampaikan. Ditinjau dari penerapan lima hukum retorika menurut Aristoles, K.H. Junaedi Al-Baghdadi menerapkan kelima hukum tersebut akan tetapi pada tahap penyusunan materi beliau tidak menyusun materi sebelum ceramah, karena metode dakwah yang beliau gunakan adalah metode cinta dan ikhlas yang mengalir apa adanya. Selain itu beliau juga menerapkan konsep ethos, pathos, dan logos. Tiga konsep tersebut beliau terapkan pada pesan-pesan yang disampaikan agar pesan tersebut dapat diterima oleh akal dan pikiran serta menyentuh hati jemaahnya. beliau juga menerapkan kelima imbauan yaitu imbauan rasional, emosional, takut, ganjaran, dan motivasional. Akan tetapi K.H. Junaedi Al-Baghdadi sangat kurang dalam memberikan imbauan takut, pasalnya beliau dalam setiap ceramahnya selalu berbicara tentang kecintaan, keikhlasan, keindahan berma'rifat, sehingga sangat jarang ditemukan imbauan takut. K.H. Junaedi Al-Baghdadi menerapkan semua itu, K tidak hanya menggunakan bahasa yang bagus, indah, serta menyentuh pikiran dan hati, juga menggunakan intonasi yang sesuai agar adanya penekanan makna dari pesan tersebut.

Ketiga, tanggapan atau respons jemaah terhadap retorika K.H. Junaedi AlBaghdadi yaitu mereka mengaku bahwa retorika K.H. Junaedi Al-Baghdadi bagus, beliau juga menggunakan bahasa yang dapat dipahami oleh semua kalangan, sehingga pesan yang disampaikan dapat diterima oleh hati dan akal mereka.

Demikian jurnal ini dibuat, diharapkan penelitian ini dapat dijadikan sebagai acuan dan bermanfaat untuk penelitian selanjutnya yang akan melakukan penelitian mengenai topik yang sama dengan permasalahan yang berbeda. 
N. F. Nisa, A. Mukhlis, \& E. T. Rahman

\section{DAFTAR PUSTAKA}

Al-Baghdadi, K.H. J. (2015). Anak Lumpur Mengejar Matahari Bagian 2. Jakarta: PT. Gramedia Pustaka.

Effendy, O. U. (2013). Ilmu Komunikasi: Teori dan Praktek. Bandung: Remaja Rosda karya.

Effendy, O. U. (1993). Ilmu, Teori, dan Filsafat Komunikasi. Bandung : Citra Aditya Bakti.

Hendrikus, D. W. (1991). Retorika: Terampil berpidato, Berdiskusi, dan Bernegosiasi. Yogyakarta: Kanisius.

Munir, M. (2015). Metode Dakwah. Jakarta: Kencana.

Mushaf Aisyah. (2010). Al-Qur'an dan Terjemah Untuk Wanita. Bandung: Jabal.

Omar, T.J. (1971). Ilmu Dakwah. Jakarta: Widjaya

Rakhmat, J. (2012). Retorika Modern: Pendekatan Praktis. Bandung:

Remaja Rosda Karya.

Rakhmat, J. (2003). PsikologiKomunikasi. Bandung: Remaja Rosda Karya.

Rousydiy, T.A.L. (1989). Dasar-dasar Rhetorica Komunikasi dan Informasi. Medan : Firma Rimbow.

Sadiah, D. (2015). Metode Penelitian Dakwah: Pendekatan Kualitatif dan Kuantitatif. Bandung: PT. Remaja Rosda Karya.

Strauss, A. (2013). Basic of Qualitatif Research. Diterjemahkan oleh Muhammad Shodiq \& Imam Muttaqien. Dasar-dasar Penelitan Kualitatif. Yogyakarta: Pustaka Pelajar.

Sukayat, T. (2015). Ilmu Dakwah : Perspektif Filsafat Mabadi ‘Asyarah. Bandung: Simbiosa Rekatama Media

Syukir, A. (1983). Dasar-dasar Strategi Dakwah Islam, Al-Ikhlas, Surabaya

Tajiri, H. (2015). Etika dan Estetika Dakwah. Bandung: Simbiosa Rekatama Media.

Dinus.ac.id., Pidato: Bentuk, Tujuan, dan Metode, Diunduh pada tanggal 07 Mei 2018

Zaini, A. (2017). Retorika Dakwah Mamah Dedeh dalam Acara "Mamah \& Aa Berkasi" di Indosiar. dalam Ilmu Dakwab: Academic Journal 1 for Homiletic Studies 11(2) 